KARZAN JALAL SAADOON*, NIZAR NAJIM OTHMAN**

\section{Benchmarking Perceived Quality among Gated Communities Using VIKOR: A Study from Kurdistan Region of Iraq}

Gated communities are emerging all over the world day by day. Besides, the product quality of the gated communities are still questionable in some regions. This research aims to benchmark the product quality at each gated community based on the main determinants of the product quality. To do this,data collected from 623 residents from various gated communities through questionnaire. The obtained data has been processed via structural equations modeling and integrated with VKOR other alternatives while Goizha II was the worst one.

Keywords: Product Ouality Gated Communities, Stuctual Equetions Modeling, Benchmarking, VIKO

\section{Introduction}

Product Quality is one of the most important elements which satisfies customers and in return firm obtain competitive advantage with it (Aydinli and Demir, 2015; Torlak, Demir and Budur, 2019). In order to achieve product quality, organization must define it first. On the other hand, even the product quality is once defined, it must be known that based on time, the importance of each parafirms may show some changes. From that point of view, firms should hot only define the parameters that effect product qually perceptions of customers, but also reasof time. Fur her it is vital for every organization to benchmark their ability to conform the expectations of customers more than other firms and organizations do so the they can achieve competitive advantage over others. Quality of a product and dimensions of it have been defined by various scholars (Garvin, 1984: Reeves Bednar, 1994; Sebastianelli \& Tamimi, 2002, ) in the previous researches. Garvin (1984) has defined parameters of product quality as; performance, features, reliability, conformance, durability, serviceability, aesthetics, and perceived quality. Later on, Sebastianelli \& Tamim (2002) have found the relations of those eight dimensions with three multiple definitions of quality such as user-based definition relates to aesthetics, and perceived quality, the manufacturing-based dimensions relates to conformance, and product-based quality relates to performance and features. Moreover, they couldn' relate durability, serviceability, and reliability with any of those three quality domains.

Investment on gated communities is a special field that increases the importance day by day as the populatio of the world keeps increasing. Furthermore, once the options that a customer may select increases, the competition starts. As there are more than one option to select, investors must pay more attentio to understand customer expectations and presen a better option to the users in order to keep market share and increase more. From this point of view mer expectations? And How good a brand satisfies In order to answer these questions, scientific ters iques anow Kurdistan Region of Iraq is the northern part of Iraq where gated communities have been incro sed enormously (Demir \& Mukhlis, 2017) after the United Nations Embargo in 2003 (Demir, 2014). From this point of view, the importance of product quality in gated communities has become more mportant after then. However, Demir and Mukhlis (2017) have studied the impact of product quality dimensions on the customer satisfaction, repurchase intention, and willingness to pay. They have supply, repair-maintenance...etc.) was the leading dimension which impact the perceived quality of the customers in gated communities. Furthermore, perceived quality was the main determinant which tion, and willingness to pay more.

Inis study, we have further evaluated the market leaders through benchmarking the product quality in gated communities based on the product quality imensions of Garvin (1984). To do this, we have eva 作 found that Serviceability (electricity supply, water influence customer satisfaction, repurchase inten- luated the total effects of eight product quality dimensions chen and the weights have been used for calculating VIKOR method. Based on the results, we have given advices to the managers of the gated communities in the region.

\section{Literature Review}

2.1. Product Quality

Quality is an intangible dimension which most of the times mistaken with incorrect adjectives such as durability, luxury, expensive... etc. (Crosby, 1979). There are two kinds of quality; service quality and product quality. Service qually is conforining the expectations of customer after hey pur hase any seevice (Panasuraman, ZeitDemir and Aydini, 2016; Gro Tal, and Aydill, 2015; wis and Booms (1983) stated that "Service quality is Wis measure of how well the service level delivered matches customer expectations. Delivering quality service means conforming to customer expectations on a con sistent basis." The idea has been confirmed and supported by many other scholars (Parasuraman, Zeithaml, and berry, 1988; Demir and Eray, 2015, Gronroos, 1988) Although product quality has similar aspects with the service quality by means of conforming the expectations (Demir, Eray, and Erguvan, 2015), it contains more complicated aspects. Garvin (1984) has determined five approaches of product quality such as:

- Transcendent approach which means innate excellence of product. It is the philosophical aspect of the quality that has been initiated by the Plato's discussion of beauty (Dickie, 1971)

Product based approach which means the main characteristics of a product that it cannot be evaluated without those characteristics (Garvin, 1984; Griliches, 1971)

- User based approach which defines quality from the end users' points of view.It can be simply defined as fitness for use (Gilmore, 1974)

Manufacturing based approach which focuses on the supply side of the production and primarily cares about the engineening or manufacturng problems (Garvin 1984). Simply it aims to "do it right at the first time for the conformance of customer ixpectalions" (Crosby, 1979) and based approach dernes quality in terms of price and cost of it. By an Garvin (1984) has derived mainly eight dimensions from the five approaches mentioned above. Those dimensions have been;

1. Performance

2. Features

3. Reliability

4. Conformance

5. Durability

6. Serviceability

7. Aesthetic

8. Perceived quality

The current research has been studied based on those eight dimensions of product quality. The research cons- ders gated communities as product and those prother based on the determinants of product quality.

2.2. VIKOR Method

Multi-Criteria Decision-Makinganalysis include many tools such as analytic hierarchy process, TOPSIS, VIKOR...etc. Which have been used to compare alternatives (Demir, 2019), rank the importance of each criterion (Ozmen, Demir, and Celepli, 2013)...etc. Further, VIKOR method is one of the multi criteria decision-making analysis that determines the compromise ranking list of proms, compromise solutions for complex choichs, and the weight stabilly intervals for tained with the initil given weights (Opricovic o Tzeng, 2004). The model gives best alternic as solution that is closest to the ideal (Opricovic, 1998). Steps for the VIKOR calculation are as follows (Demir, 2019);

Determine the best (f*) and the worst (f.) values among each criterion $(i=1,2,3, \ldots \ldots . n)$.

If it is a benefit criterion that is to be maximized: $f_{i}^{*}=\operatorname{Max}_{i} f_{i j}$

If it is a benefit criterion that is to be minimized: $f_{i}=\operatorname{Min} f$

Compute $S_{i}\left(E q\right.$. (1)) and $R_{i}(E q$. (2)) for $j=1,2,3 \ldots \mathrm{m}$. $S_{i}$ and $R_{i}$ respectively represent utility and regret measures for alternative.

$\mathrm{S}_{\mathrm{j}}=\sum_{j=1}^{n}\left[w_{i}\left(\frac{f_{i}{ }^{*}-f_{i j}}{f_{i}{ }^{*}-f_{i}{ }^{*}}\right)\right]$

$\mathrm{R}_{\mathrm{j}}=\sum_{j=1}^{n} \max _{j}\left[w_{i}\left(\frac{f_{i}{ }^{*}-f_{i j}}{f_{i}{ }^{*}-f_{i}{ }^{*}}\right)\right]$

Where $\mathrm{w}_{\mathrm{i}}$ is the weight of the criterion Compute $Q_{j}$ (Eq. (3)) for $j=1,2,3 \ldots, m$ where $S^{\prime \prime}=\min S_{j}, S^{=}=\max S_{j}, R^{*}=\min R_{j}, R=$ max $R_{j}$, $v$ is the weight for the decision-making strategy of the maximum group utility and (1-v) $v$ is assugh of the individual regret, generally sensus.

$\mathrm{Q}_{\mathrm{i}}=\sum_{j=1}^{n}\left[\mathrm{v}\left(\frac{S_{i}-S_{i}{ }^{-}}{S_{i^{*}}{ }^{-}-S_{i}{ }^{-}}\right)+(1-\mathrm{v})\left(\frac{R_{i}-R^{-}}{R^{*}-R^{-}}\right)\right]$(3)

Rank the alternatives by the values $S, R$ and $Q$ in ascending order by forming three ranking lists such hat the lower the value the better the alternative. Propose the alternative $a^{\prime}$ as a compromise solution which is ranked the best by the minimum value of $Q$ if the following two conditions are satisfied: Condition 1. Acceptable advantage: $O\left(a^{\prime \prime}\right)-O\left(a^{\prime}\right)$ $D Q$ where $a^{\prime \prime}$ is the alternative which is ranked second by $\mathrm{Q}$ and $D Q=1 /\left(m^{-1}\right)$ 
Condition 2. Acceptable stability in decision making: Alternative $a^{\prime}$ must also be the best ranked by S or/and $\mathrm{R}$. If one of the conditions in Step 5 is not satisfied, propose a set of compromise solutions which include:

- Alternatives $a^{\prime}$ and $a^{\prime \prime}$ if only Condition 2 is not satisfied, or

- Alternatives $a^{\prime}, a^{\prime \prime}, \ldots, a(n)$ if only Condition 1 is not satisfied; the closeness of the alternative $a(n)$ ranked nth by $Q$ is determined by $Q(a(n))-Q\left(a^{\prime}\right)<D Q$.

2.3. Gated Communities

A gated community is a housing development on private roads closed to general traffic by a gate across the prima ry access. The developments may be surrounded by fen-

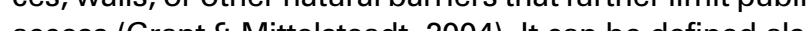
access (Grant o Mint kinds of borders to be secured and controlled by security guards (Demir \& Mukhlis, 2017). Families and individuals select to live in these developments for assorted reasons such as security, recreational facilities, ethnicity and services ...etc. (Demir \& Mukhlis, 2017).

In their much-cited study, Blakely and Snyder (1997) estimated that up to 9 million US residents live in 3 million units in around 20000 proprietary residentia communities bounded by walls and entrance gates communities bounded by walls and entrance gates,
while in 1965 there were only about 500 of these private neighborhood government. Other researchers suggest that the global growth in private communities has been influenced by the US experience, although Adham (2005) has claimed that Fatimid Cairo was a gated city (Demir \& Mukhlis, 2017).

In Kurdistan Region of Iraq, gated communities have been built enormously. The reason might be renewing the Kurdistan Region. The number of the gated communities have increased more than 10 after 2008 in Sulaimaniyah, Kurdistan Region of Iraq and still new projects are being constructed by investors. (Demir \& Mukhlis, 2017). Other reasons might be electricity, water, cleaning...etc. services also are observed not to be very sufficient in the region and needs to be improved. For these reasons, the gated communities are the places where most of the society are willing to live in.

\section{Methodology}

3.1. Sampling

The sample utilized for the study included 623 participants who were selected employing a simple random in nine different gated communities in Sulaimani, Kur distan Region of Iraq. The respondents were merely invitan to distributed in the Kurdish language. Each question was explained, and answers were recorded. The research was conducted throughout various opening hours, with 700 participants responding to the questionnaire. However, 77 of answers were incomplete and inappropriate, thus being eliminated from the study.

The margin of error and confidence interval were of vita importance to the calculation of sample size for the study. As noted by Krejcie and Morgan (1970), categorical data may have around 5\% margin of error. However, this is not always standard and might change (Kotrlik and Higgins, 2001). Thus, using Cochran's (1977) formula with $2 \%$ of the margin of error an $95 \%$ of confidence interval where $t$ value is considered to be 1.96 the sample size should be around 384. Thus, the sample used in this study is well enough to propose further analysis.

3.2. Measurement Variables

The questionnaire that has been used in this study was adopted from the study of Demir and Mukhlis (2017). There has been eight dimensions in total which are lity (four ite (six items), features (four items), reliabi(nine it h), durability (five (ive itens), aesthetics items), and perceived quality. However, testing reliability of each construct, it was observed that all the dimensions as performance $(0.809)$ features $(0.814)$ reliability (0.811) conformance $(0.894)$, aesthetics $(0.920)$ durability $(0.885)$, serviceability $(0.858)$, and perceived quality (0.872) have been reliabs8), and the Cronbach's Alpha values. In answering questionnair

In answering questionnaires five-level Likert-type Y Answers to questions ranged from 1 (strongly disagree) to 5 (strongly agree).

\subsection{Procedures}

In order to benchmark product quality of gated communities, we have initially proposed structura equations modeling to determine the importance weights of each dimension for the perceived product quality. For the next step, we have normalized the weights which are total standardized weights of each dimension on perceived quality. However, ANOVA has been proposed to determine the perceived values of each dimension (performance, $\mathrm{fe}-$ atures...etc.) at each gated community. Furthermoe, multi-criteria decision-making analysis metho has been selected among the various models.

\section{Data Analysis and Findings}

.1. Structural Equations Modeling

this section, we have proposed structura equations modeling in order to determine the imquality in gated communities. To do this, we have pes the impor lity, conformance, aesthetics, durability, and service quality on perceived quality through the mode which has been shown in the Figure 2 below. When the results of the model is observed, it has been seen that performance $\beta=0.154, p<0.05)$ features $(\beta=0.146, p<0.05)$, reliability $(\beta=0.272$, $p<0.05)$, conformance $(\beta=0.135, p<0.05)$, aesthetics $(\beta=0.135, p<0.05)$, durability $(\beta=0.167$, $p<0.05)$, and serviceability $(\beta=0.389, p<0.01)$ had directly and significantly influence on perceived quality. The table below further illustrates.

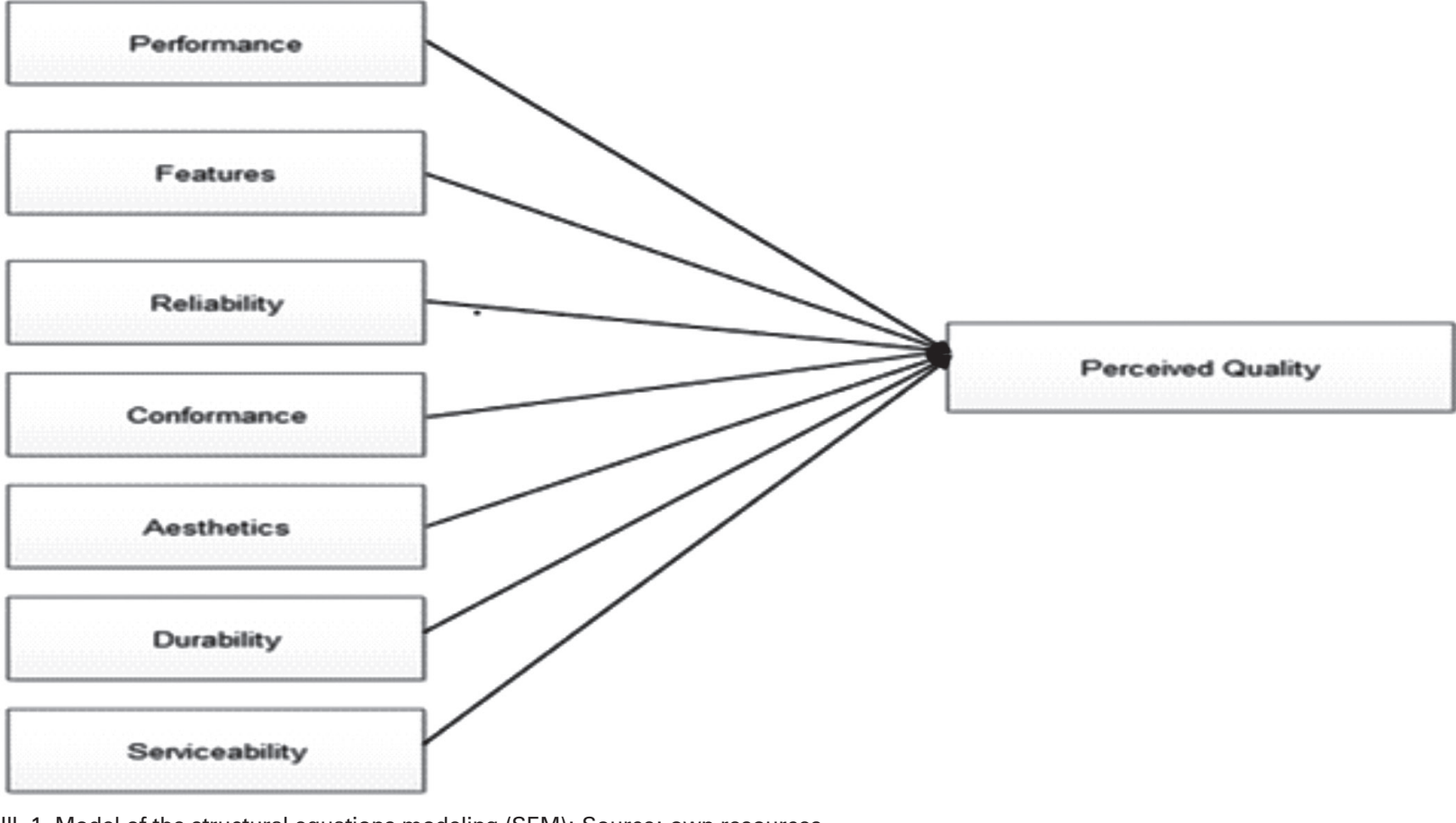

III. 1. Model of the structural equations modeling (SEM); Source: own resources

Table 1. Summary of the structural equations modeling

\begin{tabular}{|l|l|l|l|l|}
\hline Dependent & & Independent & Estimate & \multicolumn{1}{|c|}{ Signifi-ance } \\
\hline $\begin{array}{l}\text { Product } \\
\text { Quality }\end{array}$ & $<--$ & Aesthetics & 0.188 & $<0.05$ \\
\hline $\begin{array}{l}\text { Product } \\
\text { Quality }\end{array}$ & $<--$ & Performance & 0.154 & $<0.05$ \\
\hline $\begin{array}{l}\text { Product } \\
\text { Quality }\end{array}$ & $<---$ & Conformance & 0.135 & $<0.05$ \\
\hline $\begin{array}{l}\text { Product } \\
\text { Quality }\end{array}$ & $<---$ & serviceability & 0.389 & $<0.01$ \\
\hline $\begin{array}{l}\text { Product } \\
\text { Quality }\end{array}$ & $<---$ & Durability & 0.167 & $<0.05$ \\
\hline $\begin{array}{l}\text { Product } \\
\text { Quality }\end{array}$ & $<---$ & Reliability & 0.272 & $<0.05$ \\
\hline $\begin{array}{l}\text { Product } \\
\text { Quality }\end{array}$ & $<---$ & Features & 0.146 & $<0.05$ \\
\hline
\end{tabular}

Given in the table above, there are standardized estimates of independent variables on the product quality. Further, these standardized estimates have been used for the further analysis of multi-criteria decision-making analysis.

4.2. Normalization

The standardized estimates on product quality are the importance weights for the further analysis. From this point of view, those estimates can be evaluated as the importance levels of each criteria in analytic hierarchy process results. The difference is that analytic hierarchy process uses only inconsistency levels for model fit. Besides, the structural equation modeling having incremental and absolute model fit indexes which provides more accurate importance levels.
The sum of all importance levels must equal to one in order to determine the appropriate comparative importance of each criteria to one another. On the other hand, the results of structural equation modeling is not necessarily equal to one. For this reason, we have normalized standardized estimate by the formula below;

Standardized estimates of each independent variable 政 The results of the normalization is shown on the table below.

Table 2. Normalized weights
\begin{tabular}{|l|l|l|l|l|}
\hline $\begin{array}{c}\text { Depen- } \\
\text { dent }\end{array}$ & & Independent & Estimate & $\begin{array}{c}\text { Normalized } \\
\text { weights }\end{array}$ \\
\hline $\begin{array}{l}\text { Product } \\
\text { Quality }\end{array}$ & $<--$ & Aesthetics & 0.188 & 0.130 \\
\hline $\begin{array}{l}\text { Product } \\
\text { Quality }\end{array}$ & $<--$ & Performance & 0.154 & 0.106 \\
\hline $\begin{array}{l}\text { Product } \\
\text { Quality }\end{array}$ & $<-$ & Conformance & 0.135 & 0.093 \\
\hline $\begin{array}{l}\text { Product } \\
\text { Quality }\end{array}$ & $<--$ & Serviceability & 0.389 & 0.268 \\
\hline $\begin{array}{l}\text { Product } \\
\text { Quality }\end{array}$ & $<-$ & Durability & 0.167 & 0.115 \\
\hline $\begin{array}{l}\text { Product } \\
\text { Quality }\end{array}$ & $<-$ & Reliability & 0.272 & 0.187 \\
\hline $\begin{array}{l}\text { Product } \\
\text { Quality }\end{array}$ & $<--$ & Features & 0.146 & 0.101 \\
\hline $\begin{array}{l}\text { Sum } \\
\text { of total } \\
\text { stan- } \\
\text { dardized } \\
\text { effects }\end{array}$ & & & 1.451 & 1.000 \\
\hline
\end{tabular}


Table 3. Product quality values of providers for each criterion

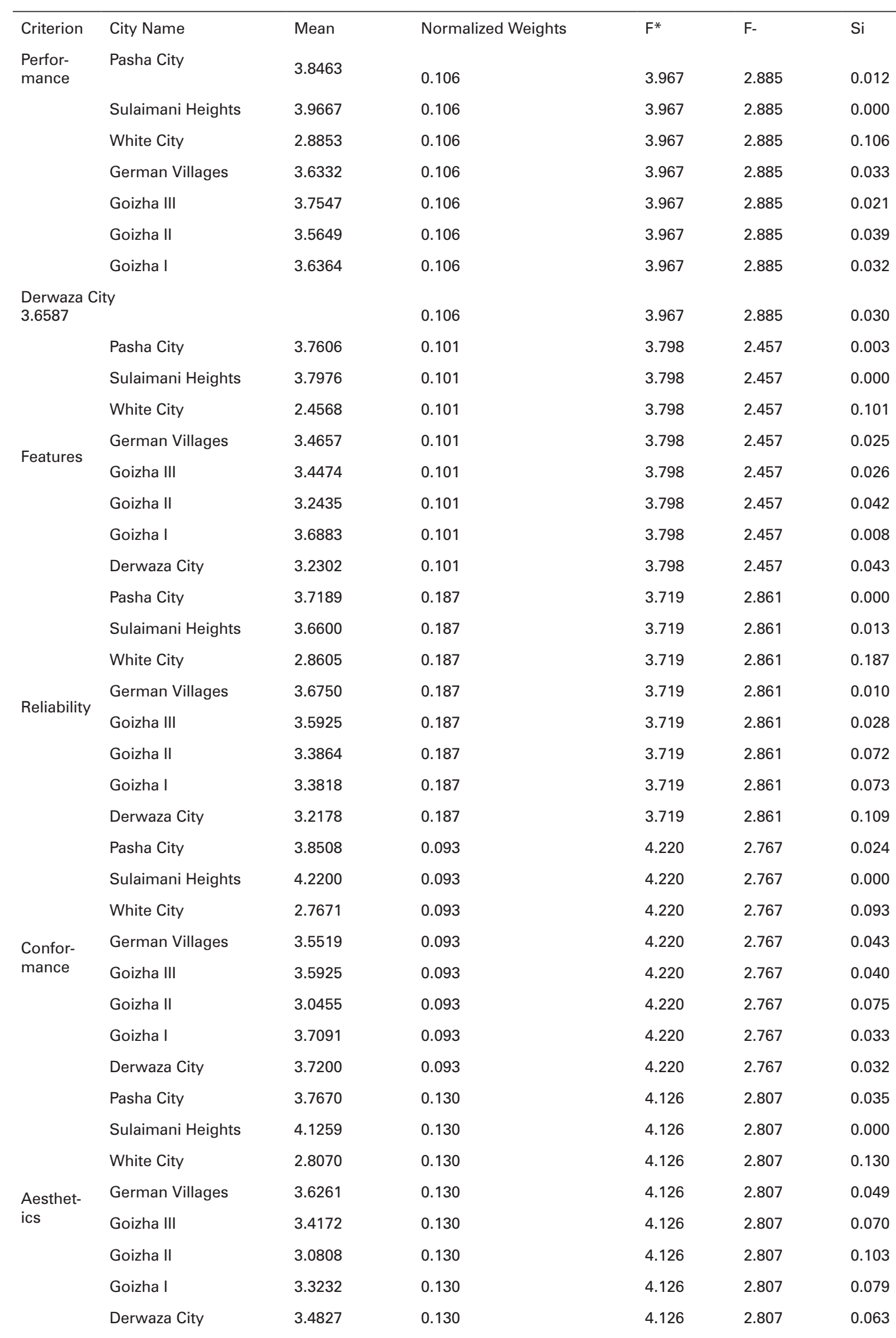

\begin{tabular}{|c|c|c|c|c|c|c|}
\hline \multirow{8}{*}{ Durability } & Pasha City & 3.6721 & 0.115 & 3.772 & 2.656 & 0.010 \\
\hline & Sulaimani Heights & 3.7722 & 0.115 & 3.772 & 2.656 & 0.000 \\
\hline & White City & 2.6557 & 0.115 & 3.772 & 2.656 & 0.115 \\
\hline & German Villages & 3.4968 & 0.115 & 3.772 & 2.656 & 0.028 \\
\hline & Goizha III & 3.2138 & 0.115 & 3.772 & 2.656 & 0.058 \\
\hline & Goizha II & 3.2083 & 0.115 & 3.772 & 2.656 & 0.058 \\
\hline & Goizha I & 3.3788 & 0.115 & 3.772 & 2.656 & 0.041 \\
\hline & Derwaza City & 3.3185 & 0.115 & 3.772 & 2.656 & 0.047 \\
\hline \multirow{8}{*}{$\begin{array}{l}\text { Service- } \\
\text { ability }\end{array}$} & Pasha City & 3.7049 & 0.268 & 4.130 & 2.687 & 0.079 \\
\hline & Sulaimani Heights & 4.1300 & 0.268 & 4.130 & 2.687 & 0.000 \\
\hline & White City & 2.6868 & 0.268 & 4.130 & 2.687 & 0.268 \\
\hline & German Villages & 3.4885 & 0.268 & 4.130 & 2.687 & 0.119 \\
\hline & Goizha III & 3.3849 & 0.268 & 4.130 & 2.687 & 0.138 \\
\hline & Goizha II & 3.3318 & 0.268 & 4.130 & 2.687 & 0.148 \\
\hline & Goizha I & 3.4909 & 0.268 & 4.130 & 2.687 & 0.119 \\
\hline & Derwaza City & 3.3644 & 0.268 & 4.130 & 2.687 & 0.142 \\
\hline
\end{tabular}

For the further analysis of multi-criteria decision-making, normalized values have been used. The next section reduct quality at every gated community in Sulaymaniyah, Kurdistan Region of Iraq.

4.3. VIKOR

After the process of values determination, VIKOR method has been applied to evaluate the product quality gated communities in Sulaymaniyah Kurdistan Region of Iraq Proposing this method, best performing gated communities in the sector have been ranked gradually. This problem consist of eight alternatives with seven criteria. Values of each service quality for each company has been shown on the Table 3 along with the best $\left(f^{*}\right.$ and the worst $\left(f^{*}\right)$ values for each criterion.

Later on, the values of $S_{i}, S_{i}$, and $R_{i}$ and $Q$ values have been calculated and shown on the Table 4. Given in the concerning table, Si values represent distance rate of each alternative to the possible ideal solution at each criterion, $\mathrm{Sj}$ represents distance rate of each alterna-

tive to the possible ideal solution at all criterions together, $\mathrm{Rj}$ represents distance rate of each alernative to the possible the worst solution at all criterions together, Oj represents the best ideal solution among all alternatives. The details can be seen on the Table 4.

(he Table 4, Qj represents closeness to the all alternatives ideal, but competitively with the other alternatives in the same market. Results of global utility regret (Sj) and $(\mathrm{Rj})$ values show consistency with the maximum utility (Qj) that "Sulaimani Heights" is the best gated community from the product quality point of view. Besides, Derwaza City, Goizha II, and White City was the worst products among the gated communities.Details of the ranks can be seen on the Table 4. With these results, it can be concluded that "Sulaimani Heights" is the best product quality provider in Sulaimani, Kurdistan Region of Iraq.

able 4. Ranking resuls of gated connu

\begin{tabular}{|l|c|c|c|c|c|c|c|c|c|}
\hline & $\mathrm{V}$ & $\mathrm{Sj}$ & $\mathrm{Rj}$ & $\mathrm{S}-$ & $\mathrm{S}+$ & $\mathrm{R}-$ & $\mathrm{R}+$ & $\mathrm{Oj}$ & Rank \\
\hline Pasha City & 0.5 & 0.163 & 0.079 & 1.000 & 0.013 & 0.268 & 0.013 & 0.206 & 2 \\
\hline Sulaimani Heights & 0.5 & 0.013 & 0.013 & 1.000 & 0.013 & 0.268 & 0.013 & 0.000 & 1 \\
\hline White City & 0.5 & 1.000 & 0.268 & 1.000 & 0.013 & 0.268 & 0.013 & 1.000 & 8 \\
\hline German Villages & 0.5 & 0.307 & 0.119 & 1.000 & 0.013 & 0.268 & 0.013 & 0.357 & 3 \\
\hline Goizha III & 0.5 & 0.381 & 0.138 & 1.000 & 0.013 & 0.268 & 0.013 & 0.432 & 5 \\
\hline Goizha II & 0.5 & 0.538 & 0.148 & 1.000 & 0.013 & 0.268 & 0.013 & 0.531 & 7 \\
\hline Goizha I & 0.5 & 0.385 & 0.119 & 1.000 & 0.013 & 0.268 & 0.013 & 0.396 & 4 \\
\hline Derwaza City & 0.5 & 0.466 & 0.142 & 1.000 & 0.013 & 0.268 & 0.013 & 0.483 & 6 \\
\hline
\end{tabular}




\section{Conclusion}

The aim of this paper was to benchmark the product quality of the gated communities in Sulaimani, Kurdistan Region of Iraq. To do this, we have gathered data from various gated communities and proposed structural equations modeling in order to obtain the coefficient values of the determinant dimensions. The coefficient values have been integrated with the VIKOR method in order to propose the benchmarking.

The results show us that serviceability and reliability were the main parameters which impact the product quality perceptions of the customers respectively. With these results, the city managers must care about the serviceability in their gated communities for increasing the product quality perceptions of the customers. To do this, they can;

Provide convenient payment system of services and products such as electricity, water, monthly service expenditures...etc.

They can create an online payment system which will make customers pay the bills online through their credit cards.

Create a fast maintenance team who will behave friendly, responsive, and do their job reliably while solving problems or repairing the tools.

The benchmarking results show that "Sulaimani Heights" is the best product quality provider among other alternative gated communities. Besides, based on the observations, it can be revealed that it is the most expensive gated community, also. This might be a disadvantage for the investors. Further, researchers must consider this problem in the next studies.

When the site difficulties and limitations of the current study is considered, it can be concluded that data collection was the most problematic part of the research. The residents haven't been keen on filling the survey questionnaire. Secondly, it was hard to get permission from the managers to contact with the residents who are the customers on the gated community investors. The research has been conducted only in Sulaimani and cannot be generalized to all Iraq. The following researchers can collect data from all Iraq in order to draw a more general picture of the country.

\section{BIBLIOGRAPHY}

[1] Adham, K. (2005). Globalization, neoliberalism, and new spaces of capital in Cairo. Traditional Dwellings and Settlements Review, 17(1), 19

[2] Aydinli, C., \& Demir, A. (2015). Impact of non-technical dimensions of service quality on the satisfaction, loyalty, and the willingness to pay more: a cross-national research on GSM operators. International Journal of Economics, Commerce and Management, 3(11), 1-16.

[3] Blakely, E. J., \& Snyder, M. G. (1997). Divided we fall: Gated and walled communities in the United States. Architecture of fear, 85-99.

[4] Crosby, P. B. (1979). Quality is free: The art of making quality certain (Vol. 94). New York: McGraw-hill.

[5] Demir, A., \& Aydinli, C. (2016). Exploring the Quality Dimensions of Mobile Instant Messaging Applications and Effects of Them on Customer Satisfaction. International Journal of Computer Theory and Applications, 9(22), 1-15.

[6] Demir, A., \& Mukhlis, M. (2017). An evaluation of gated communities as a product: An empirical study in Sulaimaniyah, Iraq. Theoretical and Empirical Researches in Urban Management, 12(3), 63-84.

[7] Demir, A. (2019. A Benchmarking of Service Quality in Telecommunication Services: Case Study in Kurdistan Region of Iraq. International Journal of Social Sciences \& Educational Studies. 5 (3), 216-231.

[8] Demir, A., \& Eray, O. (2015). Effect of Non-Technical Dimensions of Service Quality on "Satisfaction","Loyalty", and "Willingness to Pay More" of the Customers: the Case of Georgian Internet Service Providing Companies. Journal of Research in Business, Economics and Management, 5(1), 500-508.

[9] Demir, A., Eray, O., \& Erguvan, M. M. (2015). How non-technical dimensions of service quality effects satisfaction and loyalty of costomers at gsm service sector in Georgia. International Journal of Engineering Technology and Scientific Innovation, 1(02), 150-162.

[10] Demir, A., Talaat, K., \& Aydinli, C. (2015). The Relations among Dimensions of Service Quality, Satisfaction, Loyalty, and Willingness to pay more: Case of GSM Operators Service at Northern-Iraq. International Journal of Academic Research in Accounting, Finance and Management Sciences, 5(4), 146-154.

[11] DICKIE, G.L. (1971) Aesthetics: An Introduction, New York: Pegasus.

[12] Garvin, D. A. (1984). What Does "Product Quality" Really Mean. Sloan management review, 25

[13] Gilmore, H. L. (1974). Product conformance cost. Quality progress, 7(5), 16-19

Griliches, Z. (1971). Price indexes and quality change: Studies in new methods of measurement. Harvard University Press.

[14] Grant, J., \& Mittelsteadt, L. (2004). Types of gated communities. Environment and planning B: Planning and Design, 31(6), 913-930.

[15] Gronroos, C. (1988). Service quality: The six criteria of good perceived service. Review of business, 9(3), 10.

[16] Özmen, Ö., Demir, A., \& Celepli, M. (2013). An Analysis of Iraq's Pre-import Inspection, Testing \& Certification Program: A'WOT Analysis. Procedia-Social and Behavioral Sciences, 99, 85-93.

[17] Parasuraman, A., Zeithaml, V. A., \& Berry, L. L. (1985). A conceptual model of service quality and its implications for future research. Journal of marketing, 49(4), 41-50.

[18] Theil, H. (1971). Principles of econometrics (No. 04; HB139, T44.). New York: John Wiley \& Sons.

[19] Torlak, N. G., Demir, A., \& Budur, T. (2019). Impact of operations management strategies on customer satisfaction and behavioral intentions at café-restaurants. International Journal of Productivity and Performance Management. https://doi.org/10.1108/IJPPM-01-2019-0001 